\title{
Pemilihan Supplier Industri Manufaktur dengan Pendekatan AHP dan TOPSIS
}

\author{
Lukmandono $^{1}$, Minto Basuki ${ }^{2}$, M Junaidi Hidayat ${ }^{3}$, Viky Setyawan ${ }^{1}$ \\ ${ }^{1}$ Jurusan Teknik Industri \\ ${ }^{2}$ Jurusan Teknik Perkapalan \\ ${ }^{3}$ Jurusan Desain Produk \\ Institusi Teknologi Adhi Tama Surabaya \\ Jl. Arief Rachman Hakim 100, Surabaya 60117 \\ email :lukmandono@itats.ac.id \\ doi: https://doi.org/10.31315/opsi.v12i2.3146
}

Received: $9^{\text {th }}$ October 2019; Revised: $28^{\text {th }}$ October 2019; Accepted: $30^{\text {th }}$ December 2019; Available online: 31 st December 2019; Published regularly: December 2019

\begin{abstract}
The problem in this research is to determine the criteria and criteria weights from the suppliers. PT. KBP is a manufacturing company engaged in the manufacture of export shoes with the main raw material for leather and supporting raw material for heels. The products produced are various kinds of fashion model shoes for adult women, including boots, mid boots, sneakers, and sandals. During this time, the company set suppliers based on the price offered and the number of goods. This study aims to establish the criteria and sub-criteria used as aspects of consideration for selecting suppliers based on company conditions to produce the best supplier decisions. The method used in this study is AHP and TOPSIS. AHP is used as a weighting of criteria and sub-criteria, while TOPSIS is used to determine alternative priorities that are close to positive ideal solutions. This study uses seven criteria and 17 sub-criteria. The results with the AHP method obtained weighted price criteria 18.2\%, quality $28.7 \%$, delivery $11.1 \%$, flexibility $9.9 \%$, responsive $9.0 \%$, performance history $10.9 \%$, and warranty and claim policy 12.2\% whereas the TOPSIS method was obtained for PT. B is 0.710, and for supplier, G heels are 0.537. Thus PT. KBP can prioritize PT. B, as the main supplier.
\end{abstract}

Keywords: AHP; Hierarchy; Manufacturing Industry; Criteria; TOPSIS

\begin{abstract}
ABSTRAK
Permasalahan dalam penelitian ini adalah menetapkan kriteria dan bobot kriteria dari para supplier. PT. KBP merupakan perusahaan manufaktur yang bergerak dibidang pembuatan sepatu export dengan bahan baku utama leather dan bahan baku pendukung heels. Produk yang dihasilkan adalah berbagai macam sepatu model fashion untuk kalangan wanita dewasa, diantaranya sepatu boot, mid boot, sneakers, dan sandal. Selama ini perusahaan menetapkan supplier berdasarkan pada harga yang ditawarkan dan jumlah barang. Penelitian ini bertujuan untuk menetapkan kriteria dan subkriteria yang digunakan sebagai aspek pertimbangan untuk memilih supplier berdasarkan pada kondisi perusahaan agar menghasilkan keputusan supplier terbaik. Metode yang digunakan pada penelitian ini adalah AHP dan TOPSIS. AHP digunakan sebagai bobot kriteria dan subkriteria, sedangkan TOPSIS digunakan untuk menentukan prioritas alternatif yang dekat dengan solusi ideal positif. Penelitian ini menggunakan 7 kriteria dan 17 subkriteria. Hasil dengan metode AHP didapatkan bobot kriteria harga 18.2\%, kualitas $28.7 \%$, pengiriman $11.1 \%$, fleksibilitas $9.9 \%$, responsif $9.0 \%$, performance history $10.9 \%$ dan garansi dan kebijakan klaim 12.2\%. Sedangkan metode TOPSIS di dapatkan hasil untuk leather supplier PT. B sebesar 0.710 dan untuk heels supplier G sebesar 0.537. Dengan demikian PT. KBP dapat memprioritaskan PT. B sebagai supplier utamanya.
\end{abstract}

Kata Kunci: AHP; Hirarki; Industri Manufaktur; Kriteria; TOPSIS

\section{PENDAHULUAN}

Supplier merupakan salah satu mitra bisnis yang memegang peranan sangat penting dalam menjamin ketersediaan barang pasokan atau bahan baku yang dibutuhkan oleh perusahaan. Dalam pemenuhan kebutuhan perusahaan terkadang memiliki lebih dari satu pemasok yang dapat menimbulkan beberapa masalah terhadap pemilihan supplier yang dapat menjalin kerja sama dengan perusahaan secara berkelanjutan (Wirdianto et al., 2008).

PT. KBP adalah sebuah perusahaan manufaktur yang bergerak di bidang pembuatan 
sepatu export. Produk yang dihasilkan diantaranya jenis sepatu model fashion untuk kalangan wanita dewasa. Fokus pada penelitian ini adalah menganalisis tentang supplier bahan baku utama kulit (leather) dan supplier bahan baku heels pada sepatu fashion jenis boot. Seluruh produk yang dihasilkan oleh perusahaan ini akan didistribusikan di supermarket atau retail seluruh wilayah Indonesia dan di export.

Untuk menjaga dan memenuhi keinginan konsumen maka kualitas produk harus dikontrol dengan baik dan juga waktu pengirimannya harus tepat waktu. Perusahaan dituntut untuk memenuhi keinginan pelanggan dengan jalan mengembangkan produk dengan tepat waktu dan mampu mengeluarkan biaya yang rendah dalam bidang persediaan dan penyerahan produk. Pengelolaan industri secara cermat dan fleksibel dapat menjadikan suatu perusahaan memiliki daya saing yang tinggi dan dapat menguasai pangsa pasar (Widiyanesti, 2012).

Penelitian ini menggunakan dua metode yaitu AHP dan TOPSIS. AHP mengharuskan pengambil keputusan untuk memberikan penilaian pada pentingnya setiap kriteria dan kemudian menentukan preferensi untuk setiap alternatif keputusan mempertimbangkan semua criteria (Fu, 2014). Metode TOPSIS mengevaluasi alternatif, yaitu melakukan prioritisasi alternatif berdasarkan jarak geometris dari solusi positif-ideal dan negatifideal. Dengan demikian, dapat disimpulkan bahwa alternatif terbaik adalah yang memiliki jarak terpendek ke ideal-positif solusi, dan dengan jarak terbesar dari solusi negatif-ideal.

Metode TOPSIS merupakan metode yang berbeda dari metode alternatif lainnya, karena metode ini mudah untuk dipahami serta memperhitungkan solusi ideal dan anti-ideal. Metode TOPSIS efisien dalam memecahkan masalah peringkat, dibandingkan dengan metode lain (Rađenović, 2017). Dengan demikian, proses AHP digunakan untuk pembobotan sub kriteria, kriteria dan perhitungan intensitas sampai menghasilkan nilai yang digunakan dalam proses pada metode TOPSIS. Kemudian metode TOPSIS digunakan untuk menghitung normalisasi, normalisasi terbobot sampai solusi ideal positif dan negatif yang pada akhirnya menghasilkan nilai dari suatu kriteria (Setyadi, 2013).

\section{METODE}

Kerangka pemecahan masalah dalam penelitian ini dimulai dari identifikasi masalah, kemudian merumuskan masalah dan menentukan tujuan. setelah itu dilakukan pengumpulan data berupa (a) deskripsi perusahaan, (b) penetapan kriteria dan sub kriteria, (c) penyebaran kuesioner, dan (d) data supplier dan supplier heels. Setelah data diperoleh, maka tahap selanjutnya adalah mengolah dengan menggunakan metode AHP dan TOPSIS, kemudian dianalisa dan diakhiri dengan pengambilan simpulan dan saran.

Adapun metode pengolahan data yang digunakan dalam penelitian ini adalah AHP. AHP merupakan salah satu dari metode Multi Criteria Decision Making (MCDM) yang berperan dalam membuat formulasi dan menganalisa suatu keputusan ke dalam struktur hierarki bertingkat dari tujuan, kriteria dan alternatif (Sharma, et al., 2008). AHP pertama kali diperkenalkan oleh Thomas Saaty pada sekitar tahun 1970-an. Metode AHP dapat memecahkan persoalan dengan menggunakan kerangka berpikir yang terorganisir dan memungkinkan untuk mengambil keputusan yang tepat dan efektif terhadap persoalan tersebut. Metode AHP juga dapat digunakan untuk memunculkan bobot pada kriteria, subkriteria dan juga pada supplier (Dwiyana, 2017).

Langkah-langkah dalam metode AHP (Lukmandono, dkk, 2017) meliputi:

Mendefinisikan masalah dan menentukan penyelesaian yang diinginkan; (2) Membuat struktur hierarki dalam level yang berbeda, yaitu : puncak hierarki (goal), kriteria dan sub kriteria dimana saling berurutan (level intermediate), dan level terendah (alternatif-alternatif); (3) Membuat matriks perbandingan berpasangan. Perbandingan dilakukan berdasarkan judgment dari pengambil keputusan dengan menilai tingkat kepentingan suatu elemen terhadap elemen lainnya; (4) Melakukan perbandingan berpasangan sehingga diperoleh judgment seluruhnya sebanyak $\mathrm{n} \times[(\mathrm{n}-1) / 2]$ buah, dengan $\mathrm{n}$ adalah banyaknya elemen yang dibandingkan; (5) Menghitung nilai eigen dan menguji konsistensinya, jika tidak konsisten maka pengambilan data diulangi; (6) Mengulangi langkah 3, 4, dan 5 untuk seluruh tingkat hierarki; (7) Menghitung eigen vector dari setiap matrik perbandingan berpasangan. nilai eigen vector merupakan bobot setiap elemen. Langkah ini untuk mensintesis judgment dalam penentuan prioritas elemen-elemen pada tingkat hierarki terendah sampai pencapaian tujuan; (8) Memeriksa konsistensi hierarki. Jika nilainya 
lebih dari $10 \%$ maka penilaian data judgment harus diperbaiki.

Metode TOPSIS merupakan salah satu dari metode MCDM, untuk digunakan dalam pengambilan keputusan dari beberapa alternatif yang tersedia. Metode ini tidak hanya memiliki jarak terpendek dari solusi ideal positif, namun juga yang memiliki jarak terjauh dari solusi ideal negative, sehingga dapat digunakan sebagai pengambil keputusan secara praktis. Solusi ideal positif dengan cara memaksimalkan kriteria manfaat dan meminimalkan kriteria biaya. Begitu juga sebaliknya dengan solusi ideal negatif, memaksimalkan kriteria biaya dan meminimalkan kriteria manfaat (Febriansyah J, 2017) .

Adapun langkah - langkah metode TOPSIS

(Rađenović, 2017) ) adalah sebagai berikut:

1. Membangun sebuah matriks keputusan

Bobot alternatif dari setiap subkriteria disejajarkan dalam satu kolom untuk terlihat secara keseluruhan.

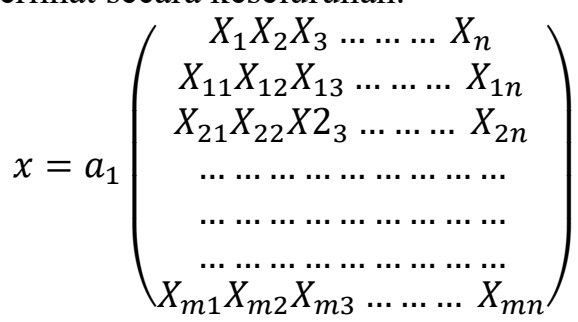

2. Menghitung matriks ternormalisasi

Keputusan ternormalisasi, persamaan yang digunakan untuk mentransformasikan setiap elemen $x_{i j}$ adalah rating pada masing - masing kriteria ataupun subkriteria yang ternormalisasi.

$$
\mathrm{r}_{\mathrm{ij}}=\frac{x_{i j}}{\sqrt{\sum_{i=1}^{m} X_{i j}^{2}}}
$$

3. Membangun matriks keputusan ternormalisasi terbobot

Menghitung nilai ternormalisasi terbobot dengan mengalikan nilai pada tiap alternatif dari matriks ternormalisasi dengan bobot yang diberikan pengambil keputusan.

$$
\mathrm{V}=\begin{array}{cccc}
w_{1} r_{11} & w_{1} r_{11} & \ldots & w_{1} r_{11} \\
w_{1} r_{11} & w_{1} r_{11} & \ldots & w_{1} r_{11} \\
\vdots & \vdots & \ddots & \vdots \\
w_{1} r_{11} & w_{1} r_{11} & \ldots & w_{1} r_{11}
\end{array}
$$

4. Menentukan solusi ideal positif dan solusi ideal negatif
Solusi ideal positif disimbulkan dengan $\left(\mathrm{A}^{+}\right)$dan solusi ideal negatif disimbulkan dengan $\left(\mathrm{A}^{-}\right)$.

$A^{+}=\left\{\max \mathrm{V}_{i j}\left|j \in \mathrm{J}, \min \mathrm{V}_{i j}\right| j \in \mathrm{J}^{\prime \prime}, I=\right.$ $1,2,3, \ldots . ., \mathrm{m}\}$

$=\left\{1^{+}, \mathrm{V}^{+}, \ldots . ., \mathrm{Vn}^{+}\right\}$

$A^{-}=\left\{\min \mathrm{V}_{i j}\left|j \in \mathrm{J}, \max \mathrm{V}_{i j}\right| j \in \mathrm{J}^{\prime \prime}, I=\right.$ $1,2,3, \ldots . ., \mathrm{m}\}$

$=\left\{1^{-}, \mathrm{V} 2^{-}, \ldots . ., \mathrm{Vn}^{-}\right\}$

5. Menghitung separasi

Menghitung jarak antara nilai setiap alternatif dengan matriks solusi ideal positif dan matriks solusi ideal negatif. $\mathrm{Si}^{+}$adalah jarak alternatif dari solusi ideal positif didefinisikan sebagai berikut:

$\mathrm{Si}^{+}=\sqrt{\sum_{j=1}^{n}\left(V_{i j}-V_{j}^{+}\right)^{2}}$

$\mathrm{Si}^{-}$adalah jarak alternatif dari solusi ideal negatif didefinisikan sebagai berikut:

$\mathrm{Si}^{-}=\sqrt{\sum_{j=1}^{n}\left(V_{i j}-V_{j}^{-}\right)^{2}}$

6. Menghitung kedekatan relatif terhadap solusi ideal

$C i+=\frac{s_{i}^{-}}{s_{i}^{+}+s_{i}^{-}}$

7. Merangking alternatif

Perangkingan dilakukan untuk mendapatkan prioritas pada setiap alternatif berdasarkan nilai urutan $\mathrm{Ci}^{+}$.

\section{HASIL DAN PEMBAHASAN}

PT. KBP mempunyai 3 alternatif supplier leather, yaitu supplier A, B dan C, dan 4 alternatif supplier heels, yaitu supplier F, G, H dan I. Perusahaan akan memilih kriteria sesuai dengan jenis bahan baku yang dipasok (Dwiyana $R, 2017)$. Berdasarkan kondisi perusahaan saat penelitian, digunakan 7 kriteria dalam memilih supplier, yaitu : harga, kualitas, pengiriman, fleksibilitas, responsif, performance history dan garansi atau kebijakan klaim. Setelah menetapkan kriteria tahap selanjutnya adalah menentukan sub kriteria dengan cara menyebarkan kuesioner yang melibatkan pihak internal perusahaan yang terdiri dari purchasing dan PPIC, dan didapatkan 17 sub kriteria yang akan digunakan. Hirarki pemilihan supplier untuk leather digambarkan pada Gambar 2. 


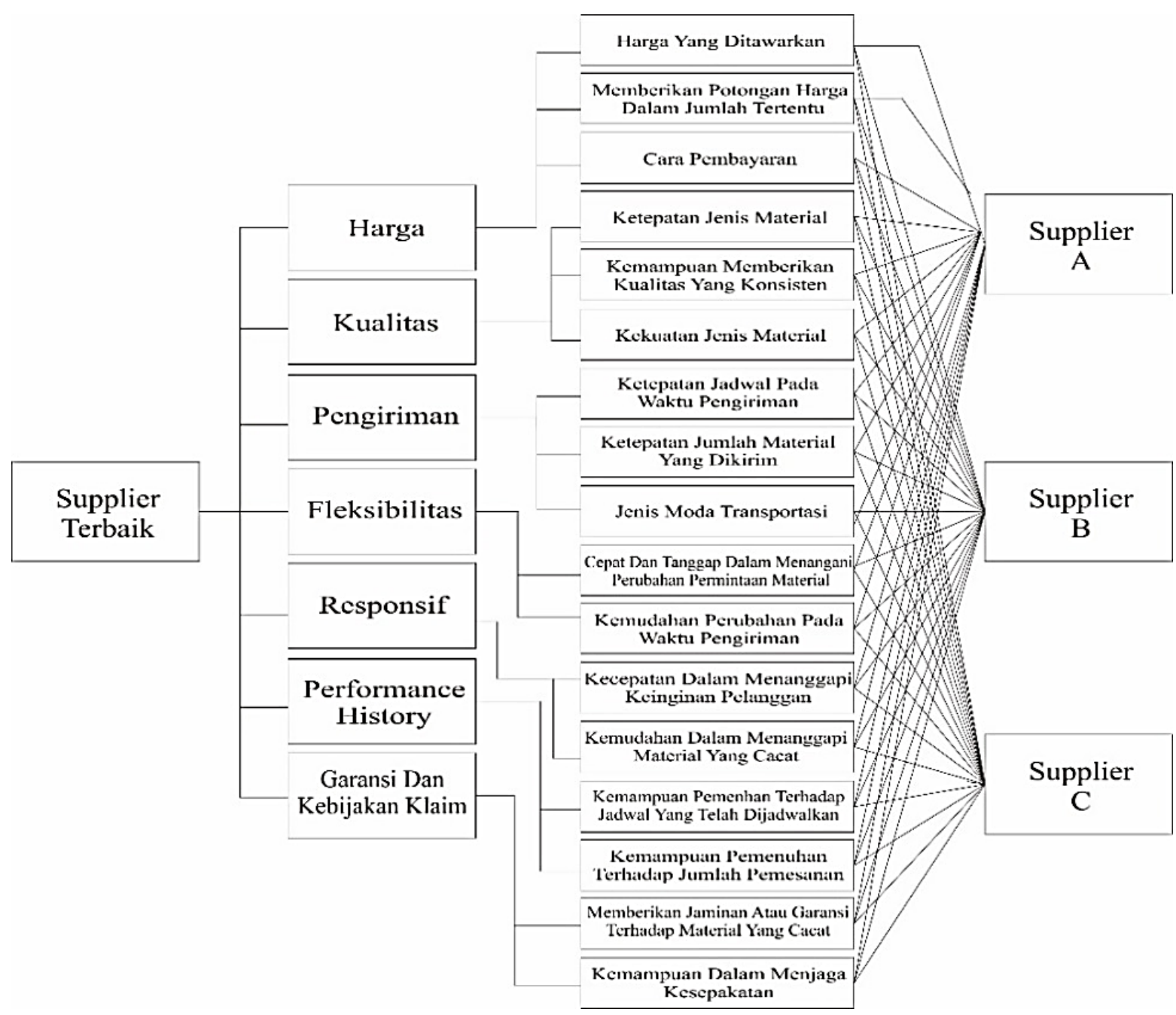

Gambar 2. Hirarki Pemilihan Supplier Leather

Dengan menggunakan langkah-langkah metode AHP seperti dalam paparan teori serta dengan bantuan software Expert Choice, didapatkan hasil pembobotan sebagai berikut :

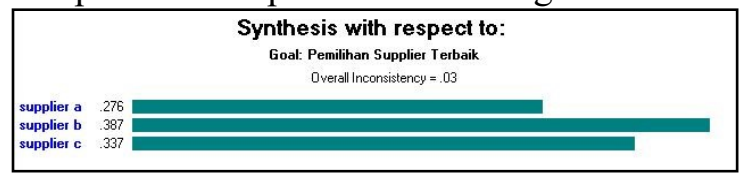

Gambar 3. Gambar Sintesis Pemilihan Supplier untuk Leather

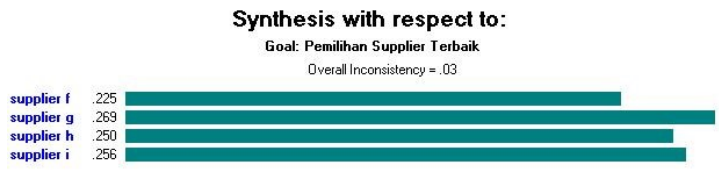

Gambar 4. Gambar Sintesis Pemilihan Supplier untuk Heels

Dari Gambar 3 dan Gambar 4 terlihat bahwa untuk supplier leather, urutan rangkingnya adalah supplier B dengan bobot 0,387 , supplier $\mathrm{C}$ dengan bobot 0,337 dan supplier A dengan bobot 0,276. Sedangkan untuk supplier heels, urutan rangkingnya adalah supplier $\mathrm{G}$ dengan bobot 0,269 , supplier I dengan bobot 0,256 , supplier $\mathrm{H}$ dengan bobot 0,25 dan supplier A dengan bobot 0,225 . Hasil sintesis supplier leather dan heels telah melalui uji konsistensi dan konsisten dengan nilai CR (overall consistency) dibawah $10 \%$.

Hasil pembobotan dengan metode AHP ini kemudian dilanjutkan dengan pendekatan metode TOPSIS yang dapat memberikan perankingan pada setiap alternatif supplier berdasarkan pada jarak setiap skor dengan nilai tertinggi dan terendah setiap sub kriteria. Dengan demikian supplier yang menjadi prioritas utama memiliki jarak terdekat dengan solusi ideal positif dan memiliki jarak terjauh dengan solusi ideal negatif pada setiap sub kriteria berdasarkan setiap kriteria yang telah ditentukan.

Dengan mengabungkan hasil pembobotan dengan AHP serta menggunakan langkahlangkah metode TOPSIS melalui persamaan (1), 
(2), (3), (4), (5), (6), (7), dan (8) didapatkan hasil rekapitulasi yang ditampilkan pada Tabel 1 .

Tabel 1. Rekapitulasi Metode AHP vs Metode TOPSIS

\begin{tabular}{cccccc}
\hline $\begin{array}{c}\text { Jenis } \\
\text { Bahan }\end{array}$ & $\begin{array}{c}\text { Alternatif } \\
\text { Supplier }\end{array}$ & AHP & Ranking & TOPSIS & Ranking \\
\hline \multirow{4}{*}{ Leather } & A & 0,276 & 3 & 0,264 & 3 \\
& B & 0,387 & 1 & 0,710 & 1 \\
\hline \multirow{4}{*}{ Heels } & C & 0,337 & 2 & 0,354 & 2 \\
\hline \multirow{7}{*}{} & F & 0,225 & 4 & 0,343 & 4 \\
& H & 0,269 & 1 & 0,537 & 1 \\
\hline
\end{tabular}

Dari Tabel 1 dapat diketahui supplier yang memiliki bobot dan kedekatan relatif terbesar adalah supplier B untuk leather pada pengolahan data metode AHP dan TOPSIS, sedangkan supplier yang memiliki bobot dan kedekatan relatif terbesar untuk heels adalah supplier $\mathrm{G}$ pada pengolahan data metode AHP dan TOPSIS. Metode AHP digunakan untuk menentukan bobot saja dengan cara menyusun hierarki, menentukan prioritas dan menentukan konsistensi logis, sedangkan pada metode TOPSIS dilakukan perhitungan dengan beberapa cara yaitu membangun sebuah matriks keputusan, menghitung matriks ternomalisasi, membangun matriks keputusan ternormalisasi terbobot, menentukan solusi ideal positif dan negatif, menghitung separasi, menghitung kedekatan relatif terhadap solusi ideal dan merangking alternatif sehingga menghasilkan pemilihan supplier yang kompleks.

\section{KESIMPULAN}

Kesimpulan dari hasil penelitian ini adalah terdapat 7 kriteria yang digunakan sebagai dasar pemilihan supplier, yaitu harga, kualitas, pengiriman, fleksibilitas, responsif, performance history dan garansi dan kebijakan klaim.

Hasil perhitungan performansi supplier dengan menggunakan metode AHP dan metode TOPSIS didapatkan hasil supplier terbaik untuk bahan baku utama leather yaitu PT. B dengan nilai sebesar 0,710 dan supplier terbaik pada bahan baku pendukung heels yaitu PT. G dengan nilai 0,537. Dengan demikian PT. KBP dapat memprioritaskan PT. B sebagai supplier utamanya.

\section{UCAPAN TERIMA KASIH}

Terima kasih kepada Direktorat Riset dan Pengabdian Masyarakat (DRPM) yang telah mendukung dan mendanai paper ini melalui dana hibah Penelitian Terapan Unggulan Perguruan Tinggi (PTUPT) tahun anggaran 2019 dengan nomor kontrak No. 113/SP2H/LT/DRPM/2019.

\section{DAFTAR PUSTAKA}

Dwiyana, R., Sitania, F., \& Rahayu, D., 2017, Pemilihan Supplier Tandan Buah Segar (TBS) Menggunakan Metode Analytical Hierarchy Process (AHP) Dan TOPSIS pada Pabrik Pengolahan Kelapa Sawit, Prosiding Seminar Nasional Teknologi $I V$, No. November, pp: 89-98.

Febriansyah, J., Gernowo, R., Kusumawardhani, A., 2017, Implementation Of AHP And Topsis Method To Determine The Priority Of Improving The Management of Government' $\mathrm{S}$ Assets, International Journal of Innovative Research in Advanced Engineering (IJIRAE), Vol 4, No. 03, pp: 46-53.

Fu, S., 2014, Facilitating AHP-Topsis Method For Reliability Analysis Of A Marine Lng-Diesel Dual Fuel Engine, International Journal of Performability Engineering, Vol 10, No. 5, pp: 453-466. Lukmandono, Basuki, M., \& Purnama, J., 2017, Menentukan Variabel-variabel yang Mempengaruhi Daya Saing Industri Manufaktur dengan Pendekatan AHP, Seminar dan Konferensi Nasional IDEC, Surakarta, 8-9 Mei.

Setyadi, H., 2013, Implementasi AHP Dan Topsis Untuk Penilaian DP3 Di Perguruan Tinggi, J. Ilm. Go Infotech, Vol 19, No. 1, pp: 27-34.

Sharma, M. J., Moon, I., \& Bae, H., 2008, Analytic hierarchy process to assess and optimize distribution network, Applied Mathematics and Computation, Vol 202, pp: 256-265.

Rađenović, Z. \& Veselinović, I., 2017, Integrated Ahp-Topsis Method For The Assessment Of Health Management Information Systems Efficiency, Economic Themes, Vol 55, No. 1, pp: 121-142.

Widiyanesti, S., 2012, Penentuan Kriteria Terpenting Dalam Pemilihan Supplier Di Family Business dengan Menggunakan 
Pendekatan Analytic Heirarcy Process (AHP) (Studi Kasus, Pada Perusahaan Garmen PT.X), IMAGE Jurnal Riset Manajemen, Vol 1, No. 1, pp: 45-58.
Wirdianto, E. \& Enbersa, E., 2008, Aplikasi Metode Analytical Hierarchy Process Dalam Menentukan Kriteria Penilaian Supplier, TeknikA, Vol 2, No. 29, pp: 613. 